\title{
Behavior of Alkali Metal Hydroxides/Chlorides for NO Reduction in a Biomass Reburning Process
}

\author{
Sen $\mathrm{Li}^{*}$ and Xiaolin Wei \\ Institute of Mechanics, Chinese Academy of Sciences, Number 15 Beisihuanxi Road, Beijing 100190, People’s Republic of China
}

ABSTRACT: The behaviors of alkali metal hydroxides and chlorides released from biomass for NO reduction during biomass reburning were analyzed. $\mathrm{Na}$-Containing species have great promotion of $\mathrm{NO}$ reduction by controlling the free radicals of $\mathrm{H}$ and $\mathrm{OH}$, as compared to K-containing species, and the effects of alkali metal hydroxide vapors and alkali metal chloride vapors on the NO reduction rate were identical. At the beginning stage of biomass reburning, Na-containing species can effectively inhibit the conversion of $\mathrm{HCN}$ into $\mathrm{NH}, \mathrm{HNO}$, and $\mathrm{N}$ by controlling the formation of $\mathrm{H}$ and $\mathrm{OH}$, and it avoids $\mathrm{NO}$ formation. At the later stage of biomass reburning, the free-radical levels of $\mathrm{H}$ and $\mathrm{OH}$ reach equilibrium, Na-containing species can promote the formation of $\mathrm{H}$ and $\mathrm{OH}$ to sustain a relatively high level through the chemical reaction path of $\mathrm{NaOH} \rightarrow \mathrm{Na} \rightarrow \mathrm{NaOH}$, and $\mathrm{NO}$ is effectively reduced. Because the reaction rate constant of $\mathrm{K}+\mathrm{OH}=\mathrm{KOH}$ is only ${ }^{1} / 64$ of $\mathrm{Na}+\mathrm{OH}=\mathrm{NaOH}, \mathrm{KOH}$ has low promotion of $\mathrm{NO}$ reduction, as compared to $\mathrm{NaOH}$.

\section{INTRODUCTION}

Coal combustion generates significant quantities of nitrogen oxides $\left(\mathrm{NO}_{x}\right)$, leading to the formation of both acid precipitation and photochemical smog. ${ }^{1}$ In recent years, some new combustion technologies have been developed for clean and efficient combustion. ${ }^{2}$ Reburning is one of the most promising combustion modification technologies for low-cost $\mathrm{NO}_{x}$ control, and the reburning fuel can be the same as the primary fuel or a different fuel (such as coal, biomass, gas, or fuel oil). ${ }^{1-10}$ Experiments demonstrated that biomass reburning can result in substantial $\mathrm{NO}_{x}$ reductions. ${ }^{5,6,11}$ High-volatile biomass used as burning fuel releases a large amount of the reducing agents of $\mathrm{NO}_{x}$ to significantly reduce $\mathrm{NO}_{x}$ to $\mathrm{N}_{2}$ in the reburning zone.

Experiments have found that the $\mathrm{NO}_{x}$ reduction rate could be improved $30 \%$ by adding $\mathrm{NaOH}$ into a urea solution in the process of selected noncatalytic reduction. ${ }^{12,13}$ Liu et al. ${ }^{14}$ have investigated the effects of sodium additives on the release of coal nitrogen on a thermogravimetric analyzer using Yibin coal from China. It was found that sodium compounds could reduce the release of $\mathrm{NO}$ and $\mathrm{HCN}$ remarkably, and sodium chloride $(\mathrm{NaCl})$ had a better effect on $\mathrm{NO}$ reduction than sodium carbonate $\left(\mathrm{Na}_{2} \mathrm{CO}_{3}\right)$. Avelina et al. ${ }^{15}$ have found that $\mathrm{NO}$ reduction by potassium $(\mathrm{K})$-containing briquettes was enhanced by the presence of oxygen.

Biomass has relatively high contents of alkali metals ( $\mathrm{Na}$ and $\mathrm{K}$ ), and $\mathrm{Na}$ and $\mathrm{K}$ can be released in the form of alkali metal hydroxides and chlorides (e.g., $\mathrm{KOH}, \mathrm{NaOH}, \mathrm{KCl}$, and $\mathrm{NaCl}$ ) during biomass combustion. ${ }^{3,16}$ During biomass combustion, the release of mineral compositions of biomass fuel is generally complex and difficult to quantitatively determine. It was found that alkali metals were released in the form of chlorides, hydroxides, and cyanates, ${ }^{17-19}$ and these gaseous alkali metal hydroxides and chlorides could affect NO formation when biomass is used as a reburning fuel.

Biomass reburning for $\mathrm{NO}$ reduction may require a more complete understanding of the chemical reaction pathway of $\mathrm{NO}$ reduction. The goal of this paper is to gain a better understanding of the promotion mechanisms of gaseous alkali metal hydroxides and chlorides released from biomass for NO reduction in the process of biomass reburning. Biomass reburning was simulated using the Sandia SENKIN program, and the promotion mechanisms and behaviors of $\mathrm{Na}$ - or K-containing species for $\mathrm{NO}_{x}$ reduction were analyzed.

\section{KINETIC MODEL}

Because biomass has high volatile content, it is assumed that the contribution of char combustion to NO reduction is less than that of gas-phase reactions. ${ }^{4}$ Thus, in the simulation of biomass reburning, biomass is represented as gasification products.

The chemical kinetic behavior of reactants was modeled with the Sandia SENKIN program of CHEMKIN subroutines. ${ }^{19,20}$ The program solves the conservation equations for mass and energy, and it can calculate the temporal evolution of mole fractions of species for a homogeneous mixture in a closed reactor. The SENKIN model is appropriate to investigate the promotion mechanisms of gaseous alkali metal species for NO reduction in the process of biomass reburning in a closed chamber. The reaction pathway flux analysis is performed using MixMaster, which is based on a conserved scalar approach to reaction fluxes. $^{21}$

The reaction mechanism is an extension of the reduction of $\mathrm{NO}$ by natural gas and simple hydrocarbons $(\mathrm{C} 1-\mathrm{C} 4)$ in biomass reburning conditions. ${ }^{22-25}$ The absent reactions of sodium, potassium, and chlorine are selected from refs $26-28$ and incorporated into the mechanism, and the mechanism includes 1112 reversible reactions and 181 species. The reaction mechanisms of the NO reduction by natural gas and simple hydrocarbons $(\mathrm{C} 1-\mathrm{C} 4)$ are documented in ref 25 , and the mechanisms

Received: April 30, 2011

Revised: July 7, 2011

Published: July 11, 2011 
Table 1. Fuel Analysis Properties of Furniture Waste Used as Reburning Fuel ${ }^{4}$

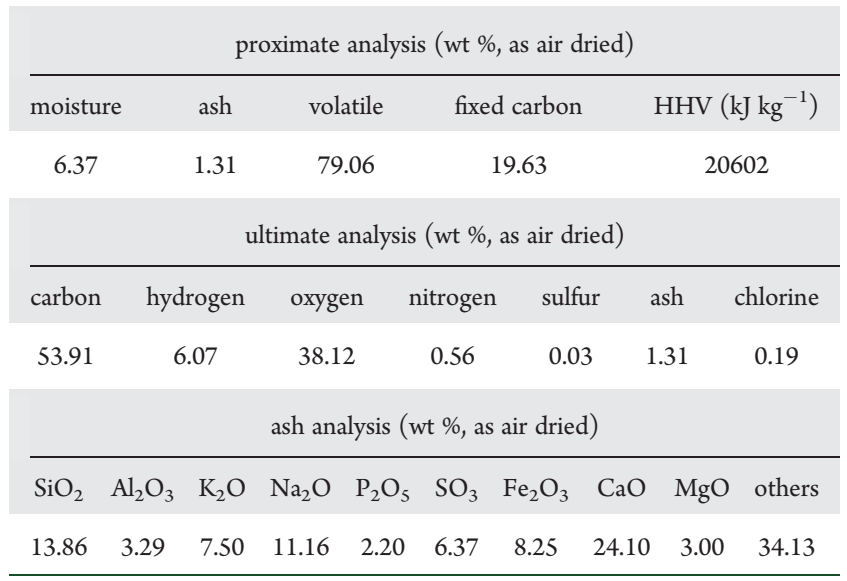

Table 2. Gasification Production Compositions of Furniture Waste (vol \%) ${ }^{26}$

\begin{tabular}{cccc}
$\mathrm{CO}$ & $\mathrm{C}_{2} \mathrm{H}_{6}$ & $\mathrm{C}_{2} \mathrm{H}_{4}$ & $\mathrm{HCN}$ \\
68.86 & 27.40 & 2.60 & 1.10 \\
\hline
\end{tabular}

involving sodium, potassium, and chlorine are documented in refs 27 and 28.

The mechanism of the reduction of $\mathrm{NO}_{x}$ by natural gas and simple hydrocarbons $(\mathrm{C} 1-\mathrm{C} 4)$ in simulated reburning conditions has been extensively validated by experimental data of biomass gas $\mathrm{NO}_{x}$ reburning in refs $22-26$, and the submechanism involving species containing sodium, potassium, and chlorine has been validated by the experimental data of alkali metals for $\mathrm{NO}_{x}$ reduction in the biomass reburning and combustion process. $^{26-29}$ The experiments of promotion of NO reduction by gaseous alkali metal hydroxides and chlorides released from biomass in the process of biomass reburning are few. It is difficult to validate the combined mechanisms for $\mathrm{NO}_{x}$ reduction. The combined mechanism may not quantitatively investigate the promotion effects of gaseous alkali metals on $\mathrm{NO}_{x}$ reduction, but it still effectively provides insight into the mechanisms and reaction pathways of the promotion of NO reduction by alkali metal elements released from biomass.

\section{SIMULATION CONDITIONS}

In the simulation of biomass reburning for NO reduction using the Sandia SENKIN model, an adiabatic system at constant pressure and temperature $(P=1.01 \mathrm{bar}$ and $T=1700 \mathrm{~K})$ is used to model the NO reduction process in the reburning zone, and the residence time of gas reactions is $0.4 \mathrm{~s}$.

GE Energy and Environmental Research Corporation has conducted an experiment of biomass reburning to demonstrate the biomass reburning technology in a $300 \mathrm{~kW}$ boiler simulator facility (BSF). ${ }^{4}$ The main fuel in the primary combustion zone was bituminous Illinois coal, and reburning fuels in the reburning zone were furniture waste pellets.

In the simulation, furniture waste is selected as reburning fuel, and the properties are presented in Table 1. The experiment demonstrated that furniture waste used as reburning fuel has a high capacity of NO reduction. ${ }^{26}$ Experimental data results suggested that the time scale of biomass gasification under these test conditions was smaller than the characteristic time of the mixing process in the reburning zone. ${ }^{4}$ The compositions of biomass gasification products are shown in Table 2.
Table 3. Initial Compositions of the Gas Mixture in the Simulation $(\text { vol \%) })^{26}$

\begin{tabular}{ccccccccc}
$\mathrm{CO}_{2}$ & $\mathrm{CO}$ & $\mathrm{C}_{2} \mathrm{H}_{6}$ & $\mathrm{C}_{2} \mathrm{H}_{4}$ & $\mathrm{HCN}$ & $\mathrm{H}_{2} \mathrm{O}$ & $\mathrm{N}_{2}$ & $\mathrm{O}_{2}$ & $\mathrm{NO}$ \\
\hline 14.93 & 3.13 & 0.86 & 0.12 & 0.05 & 7.79 & 71.27 & 1.85 & 0.004 \\
\hline
\end{tabular}

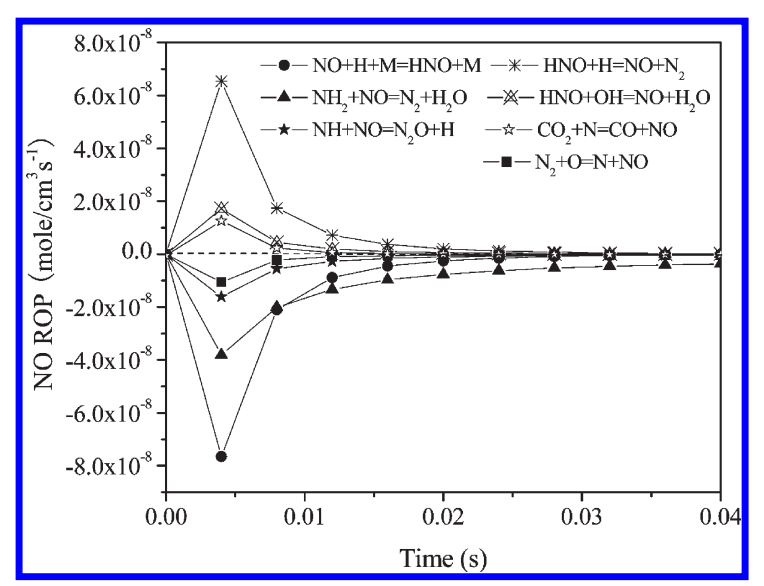

Figure 1. Rates of NO production of reactions versus the reactor time without the release of alkali metals.

The simplification of biomass gasification products is a requirement, and it is often used in computational fluid dynamic (CFD) modeling. ${ }^{30,31}$

The experiment conditions were a primary zone stoichiometric ratio (SR) of 1.10, a final SR of 1.15, and reburn fuel injected at a combustion gas temperature of about $1700 \mathrm{~K}$, with $15 \%$ reburning heat input. ${ }^{4}$ On the basis of the above experimental conditions, it is assured that the combustion of pulverized coal is complete in the primary combustion zone. The concentrations of gas coming from the primary combustion zone are calculated as follows: $1.8 \% \mathrm{O}_{2}, 15.6 \% \mathrm{CO}_{2}, 74.4 \% \mathrm{~N}_{2}$, and $8.1 \%$ $\mathrm{H}_{2} \mathrm{O}$. The biomass entering the reburning zone can be instantaneously gasified. The gasification products completely mix with flue gas coming from the primary combustion zone, and the initial compositions of the gas mixture in the simulation are shown in Table 3. NO entering the reburning zone in the experiment varied from 400 to $900 \mathrm{ppm},{ }^{4}$ and it is given at $400 \mathrm{ppm}$ in the simulation.

The available information does not allow one to identify the concentrations of alkali-metal-containing species released from the biomass to the gas phase, and it is assumed that $\mathrm{K}$ and $\mathrm{Na}$ species can be released in the vapor forms of hydroxides $(\mathrm{KOH}$ and $\mathrm{NaOH})$ and chlorides $(\mathrm{KCl}$ and $\mathrm{NaCl})$. In accordance with the content of $\mathrm{K}$ and $\mathrm{Na}$ in furniture waste, the maximum vapor concentration of alkali metal hydroxide or chloride is $28 \mathrm{ppm}$ in the initial gas mixture.

\section{SIMULATION RESULTS AND DISCUSSION}

4.1. NO Reduction by Biomass Reburning without the Release of Alkali Metals. To analyze the effect of alkali metal hydroxides/chlorides on NO in the process of biomass reburning, the chemical reaction pathways of $\mathrm{N}$-containing species are first presented without the release of alkali metal hydroxides/ chloride.

An alternative method for the study of the relevance of the reactions is the rate of production (ROP) analysis, and it is a classic method for the identification of important reaction pathways. Thus, the rates of NO production reactions are calculated, and the top seven NO production reaction rates are presented in Figure 1. When the reaction time is greater than $0.04 \mathrm{~s}$, 
NO production reaction rates are very stable and approach constants, and then these rates are not provided in Figure 1 when the reaction time varies from 0.04 to $0.4 \mathrm{~s}$. Figure 1 indicates that $\mathrm{NO}$ production rates noticeably vary at the

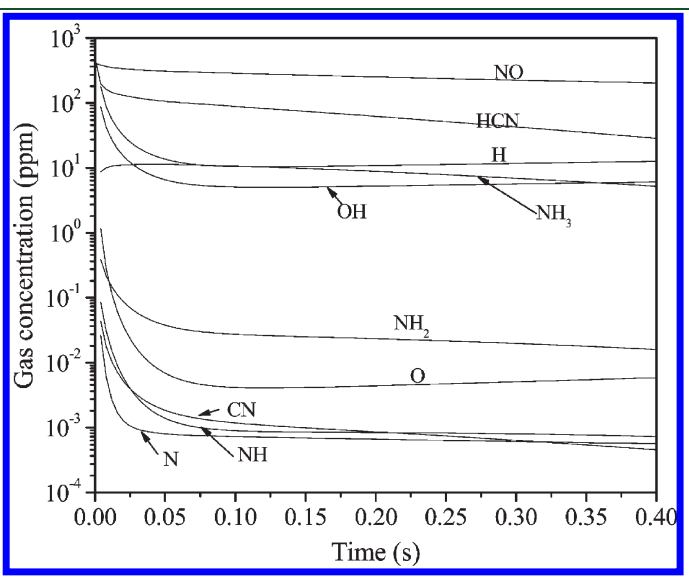

Figure 2. N-Containing species concentrations versus the residence time without the release of alkali metals. beginning time $(0-0.01 \mathrm{~s})$. The reaction $\mathrm{HNO}+\mathrm{H}=\mathrm{NO}+$ $\mathrm{N}_{2}$ plays the greatest role in $\mathrm{NO}$ formation, and the reaction $\mathrm{NO}+$ $\mathrm{H}+\mathrm{M}=\mathrm{HNO}+\mathrm{M}$ plays the greatest role in $\mathrm{NO}$ reduction. The free radicals of $\mathrm{H}, \mathrm{OH}, \mathrm{NH}, \mathrm{NH}_{2}, \mathrm{~N}$, and $\mathrm{O}$ are important for the most important reactions involving $\mathrm{NO}$ production shown in Figure 1, and the concentration profiles of these radicals are depicted in a logarithmic scale, as shown in Figure 2. At the beginning stage (reaction time of $0-0.04 \mathrm{~s}$ ) in Figure 2, freeradical concentrations vary rapidly, the concentrations of $\mathrm{HCN}$, $\mathrm{OH}, \mathrm{H}$, and $\mathrm{NH}_{3}$ are high, and the concentrations of $\mathrm{NO}, \mathrm{HCN}$, and $\mathrm{NH}_{3}$ decrease with the reaction time. At the later stage (reaction time $>0.04 \mathrm{~s}$ ), the free-radical concentrations are kept relatively steady. Thus, the beginning stage (reaction time of $0-0.04 \mathrm{~s}$ ) is crucial to $\mathrm{NO}$ reduction during biomass reburning.

To investigate NO reaction mechanisms, the reaction pathway flux analysis is performed using MixMaster (a Python program that is part of the Cantera suite), and the integral path analysis is based on a conserved scalar approach to reaction fluxes. ${ }^{32}$ Figure 3 illustrates the detailed reaction pathway diagram for $\mathrm{N}$-containing species during biomass at $t=0.004 \mathrm{~s}$, where the relative width of the arrows indicates pathway importance. Figure 3 indicates that $\mathrm{NO}$ is reduced into $\mathrm{N}_{2}$ mainly by $\mathrm{NH}_{2}$,

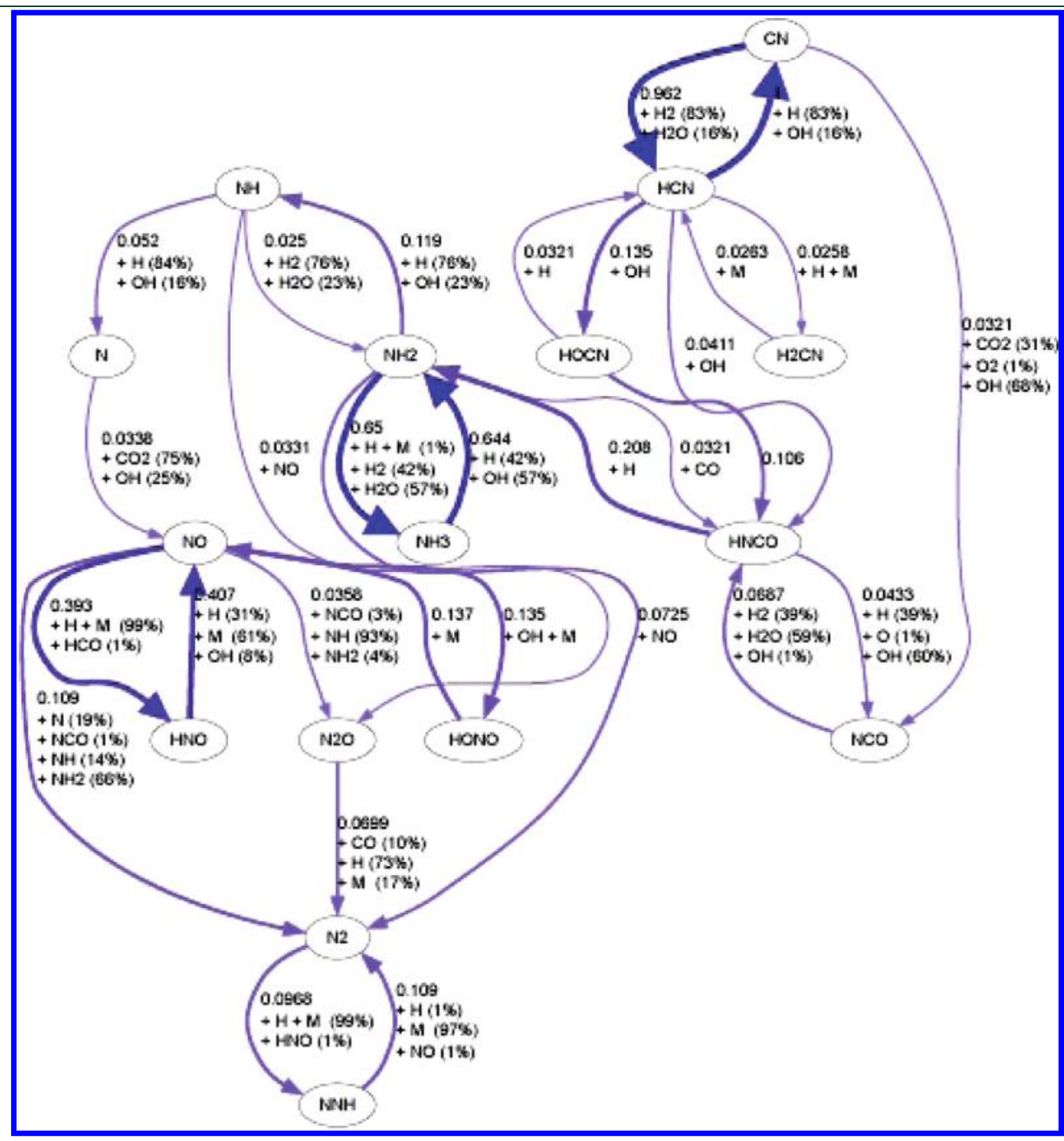

Figure 3. Reaction pathway diagram for $\mathrm{N}$-containing species during biomass reburning at $0.004 \mathrm{~s}$ without the release of alkali metals. 
$\mathrm{NH}$, and $\mathrm{N}$. The contributions of $\mathrm{NH}_{2}, \mathrm{NH}$, and $\mathrm{N}$ for $\mathrm{NO}$ reduction are 66,14 , and $19 \%$, respectively. NO-Reducing agents all derive from $\mathrm{HCN}\left(\mathrm{HCN} \rightarrow \mathrm{HOCN} / \mathrm{HNCO} \rightarrow \mathrm{NH}_{2} \rightarrow\right.$ $\mathrm{NH} \rightarrow \mathrm{N}$ ), and $\mathrm{H}$ and $\mathrm{OH}$ play a great role in the process. The detailed pathways of $\mathrm{NO}$ reduction are as follows:

(1) The detailed pathway of $\mathrm{NO}$ reduction by $\mathrm{NH}_{2}$.

$$
\begin{aligned}
& \mathrm{HCN}+\mathrm{OH} \rightarrow \mathrm{HOCN}+\mathrm{H} \\
& \mathrm{HCN}+\mathrm{OH} \rightarrow \mathrm{HNCO} \\
& \mathrm{HOCN} \rightarrow \mathrm{HNCO} \\
& \mathrm{HNCO}+\mathrm{H} \rightarrow \mathrm{NH}_{2}+\mathrm{CO} \\
& \mathrm{NH}_{2}+\mathrm{NO} \rightarrow \mathrm{N}_{2}+\mathrm{H}_{2} \mathrm{O}
\end{aligned}
$$

(2) The detailed pathway of $\mathrm{NO}$ reduction by $\mathrm{NH}$.

$$
\begin{aligned}
& \mathrm{NH}_{2}+\mathrm{OH} \rightarrow \mathrm{NH}+\mathrm{H}_{2} \mathrm{O} \\
& \mathrm{NH}_{2}+\mathrm{H} \rightarrow \mathrm{NH}+\mathrm{H}_{2} \\
& \mathrm{NH}+\mathrm{NO} \rightarrow \mathrm{N}_{2}+\mathrm{OH}
\end{aligned}
$$

(3) The detailed pathway of NO reduction by $\mathrm{N}$.

$$
\begin{aligned}
& \mathrm{NH}+\mathrm{H} \rightarrow \mathrm{N}+\mathrm{H}_{2} \\
& \mathrm{NH}+\mathrm{OH} \rightarrow \mathrm{N}+\mathrm{H}_{2} \mathrm{O} \\
& \mathrm{N}+\mathrm{NO} \rightarrow \mathrm{N}_{2}+\mathrm{O}
\end{aligned}
$$

The reaction pathway diagram also shows that NO can be produced by the following reaction pathways:

(1) $\mathrm{NO}$ formation through the reaction of $\mathrm{N}$ with $\mathrm{CO}_{2}$ and $\mathrm{OH}$.

$$
\begin{aligned}
& \mathrm{N}+\mathrm{CO}_{2} \rightarrow \mathrm{NO}+\mathrm{CO} \\
& \mathrm{N}+\mathrm{OH} \rightarrow \mathrm{NO}+\mathrm{H}
\end{aligned}
$$

(2) $\mathrm{NO}$ formation through the reaction of $\mathrm{HNO}$ with $\mathrm{OH}$ and $\mathrm{H}$.

$$
\begin{aligned}
& \mathrm{NH}+\mathrm{OH} \rightarrow \mathrm{HNO}+\mathrm{H} \\
& \mathrm{HNO}+\mathrm{OH} \rightarrow \mathrm{NO}+\mathrm{H}_{2} \mathrm{O} \\
& \mathrm{HNO}+\mathrm{H} \rightarrow \mathrm{NO}+\mathrm{H}_{2} \\
& \mathrm{HNO}+\mathrm{M} \rightarrow \mathrm{NO}+\mathrm{H}+\mathrm{M}
\end{aligned}
$$

As known from the above analysis, the reaction pathways of $\mathrm{N}$-containing species are complicated. The free radicals of $\mathrm{NH}_{2}$, $\mathrm{NH}, \mathrm{N}$, and $\mathrm{HNO}$ all derive from $\mathrm{HCN}$, where $\mathrm{OH}$ and $\mathrm{H}$ are intermediates at different stages, and these free radicals can not only reduce $\mathrm{NO}$ by $\mathrm{R} 1-\mathrm{R} 11$ but also produce NO by $\mathrm{R} 12-\mathrm{R} 17$. The net effects of $\mathrm{NH}_{2}$ and $\mathrm{NH}$ are $\mathrm{NO}$ reduction, and the net effects of $\mathrm{N}$ and $\mathrm{HNO}$ are $\mathrm{NO}$ formation. As known from Figure 1, the net rates of $\mathrm{NO}$ reduction by $\mathrm{NH}_{2}$ and $\mathrm{NH}$ are $3.81 \times 10^{-8}$ and $1.61 \times 10^{-8} \mathrm{~mol} \mathrm{~cm}^{-3} \mathrm{~s}^{-1}$, respectively, and the net rates of $\mathrm{NO}$ formation by $\mathrm{N}$ and $\mathrm{HNO}$ are $1.68 \times 10^{-8}$ and $0.61 \times 10^{-8} \mathrm{~mol} \mathrm{~cm}^{-3} \mathrm{~s}^{-1}$, respectively. Because the reaction rate constant of $\mathrm{R} 5$ is greater than that of $\mathrm{R} 8, \mathrm{NO}$ can be easily reduced by $\mathrm{R} 5$. NO reduction is dominated by the reaction $\mathrm{NH}_{2}+\mathrm{NO} \rightarrow \mathrm{N}_{2}+\mathrm{H}_{2} \mathrm{O}$.

High levels of $\mathrm{OH}$ and $\mathrm{H}$ can promote $\mathrm{NH}_{2}$ formation to easily reduce $\mathrm{NO}$ into $\mathrm{N}_{2}$, but too high levels of $\mathrm{OH}$ and $\mathrm{H}$ always make $\mathrm{NH}_{2}$ further conversed into $\mathrm{NH}, \mathrm{N}$, and $\mathrm{HNO}$ (see Figure 3), whose reaction rate constants of $\mathrm{NO}$ reduction are lower, as compared to that of $\mathrm{NH}_{2}$. Thus, the appropriate concentrations of $\mathrm{H}$ and $\mathrm{OH}$ are very important for $\mathrm{NO}$ reduction during biomass reburning at the beginning stage of biomass reburning (reaction time of $0-0.04 \mathrm{~s}$ ).

Dryer et al. ${ }^{33,34}$ have studied the oxidation of wet $\mathrm{CO}$ and found that wet $\mathrm{CO}$ oxidation occurred predominantly by the reaction $\mathrm{CO}+\mathrm{OH} \rightarrow \mathrm{CO}_{2}+\mathrm{H}$ and $\mathrm{OH}$ was 2 orders of magnitude greater than its equilibrium value. Such super-equilibrium concentrations of free radicals are quite normal in combustion chemistry at the initial combustion stage. When $\mathrm{CO}$ becomes exhausted, the ability of combustion reactions to sustain superequilibrium concentrations of free radicals decreases and the freeradical concentrations fall toward their equilibrium values at some point. ${ }^{33,34}$ Practical combustion demonstrated that the fast radical formation reactions and the relatively slow radical recombination reactions give rise to large super-equilibrium concentrations of $\mathrm{O}, \mathrm{H}$, and $\mathrm{OH}$ in the flame front zone and the equilibrium concentrations is often in the post-flame zone. ${ }^{35}$

On the basis of the above analysis, at the initial combustion stage, the super-equilibrium concentrations of free radicals are important for $\mathrm{NO}$ formation. High levels of $\mathrm{H}$ and $\mathrm{OH}$ because of $\mathrm{CO}$ oxidation at the initial stage make $\mathrm{HCN}$ conversed into not only $\mathrm{NH}_{2}$ but also $\mathrm{NH}, \mathrm{N}$, and $\mathrm{HNO}$. The reaction rate of $\mathrm{NO}$ reduction by $\mathrm{NH}$ is less than that by $\mathrm{NH}_{2}$, and $\mathrm{N}$ and $\mathrm{HNO}$ can easily produce NO. Thus, high levels of $\mathrm{H}$ and $\mathrm{OH}$ are not conducive to $\mathrm{NO}$ reduction at the initial stage of biomass reburning.

Figure 4 shows the reaction pathway diagram for $\mathrm{N}$-containing species at a later stage of biomass reburning $(t=0.2 \mathrm{~s})$. The pathway is similar to that at the initial stage (see Figure 3), and $\mathrm{NH}_{2}$ contribution increases by $21 \%$, as compared to that at $0.004 \mathrm{~s}$. As known from Figure 2, at $t>0.04 \mathrm{~s}$, the free-radical concentrations of $\mathrm{NH}_{2}, \mathrm{NH}$, and $\mathrm{N}$ are very low, which makes the $\mathrm{NO}$ reduction rate decrease. Because the $\mathrm{O}_{2}$ concentration is low during reburning, the oxidation of combustible species can be inhibited by oxygen exhaustion. The concentrations of $\mathrm{H}$ and $\mathrm{OH}$ fall toward their equilibrium values (see Figure 2). The low levels of $\mathrm{H}$ and $\mathrm{OH}$ are not conducive to the formation of $\mathrm{NO}$-reducing agents. $\mathrm{NO}$ reduction rates are approximate to 0 , except for R5, and then the NO concentration slowly decreases with the reaction time (see Figure 2).

In other words, during biomass reburning without the release of alkali metals, NO cannot effectively reduce NO because of super-equilibrium levels of $\mathrm{H}$ and $\mathrm{OH}$ at the beginning stage and too low levels of $\mathrm{H}$ and $\mathrm{OH}$ at the later stage.

4.2. NO Reduction by the Release of Alkali Metal Hydroxides. To investigate the influence of alkali metal hydroxide vapor on NO reduction during biomass reburning, the NO reduction rate is defined as

$$
\Delta \eta=\frac{C_{1, N O}-C_{2, N O}}{C_{0, N O}} \times 100 \%
$$

where $C_{0, \mathrm{NO}}$ is the initial concentration of $\mathrm{NO}(400 \mathrm{ppm})$ in the gas mixture in the simulation, as shown in Table $3, C_{1, \mathrm{NO}}$ is the $\mathrm{NO}$ emission concentration in the absence of alkali metal vapor, 


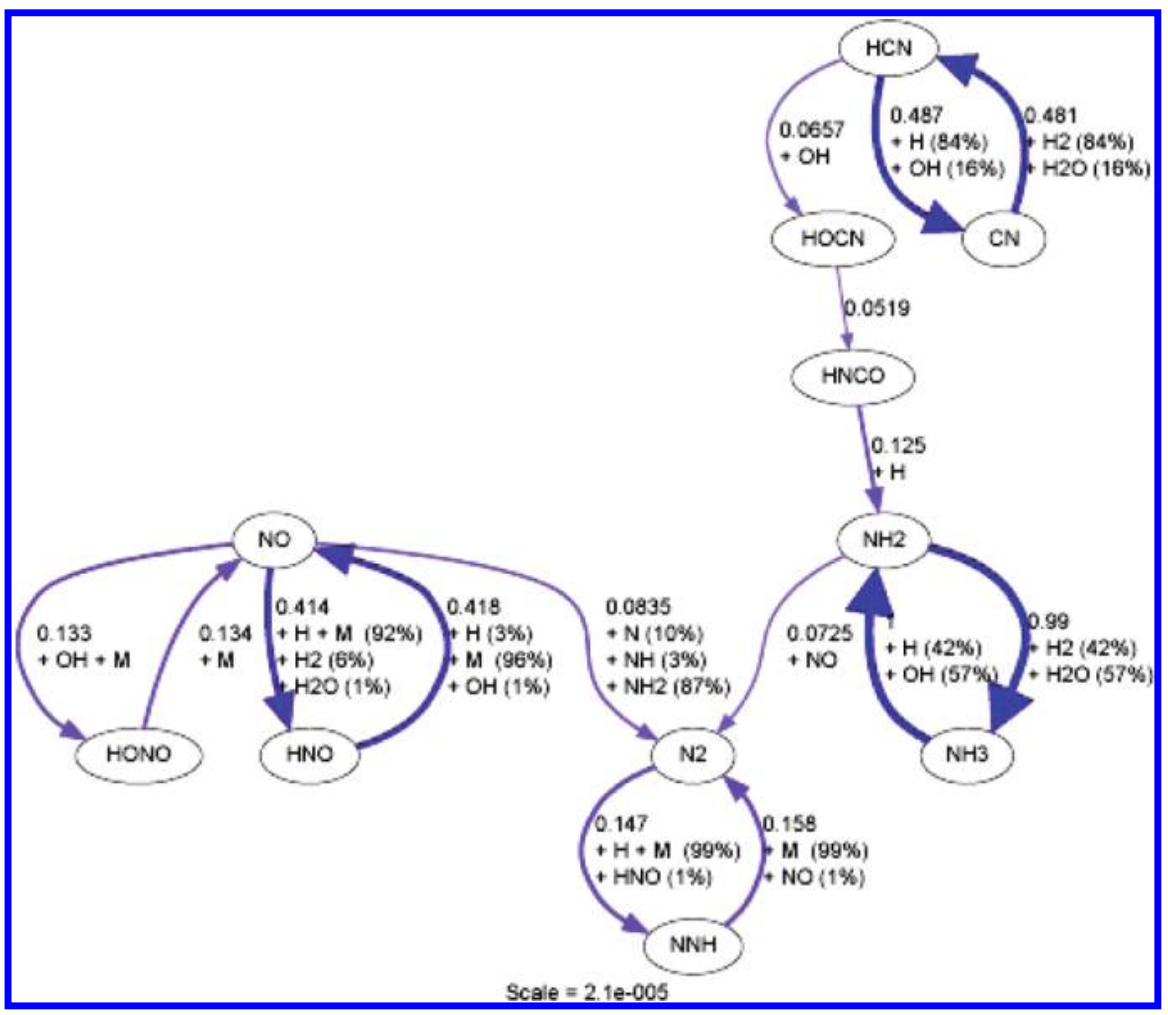

Figure 4. Main reaction pathway diagram for $\mathrm{N}$-containing species during biomass reburning at $0.2 \mathrm{~s}$ without the release of alkali metals.

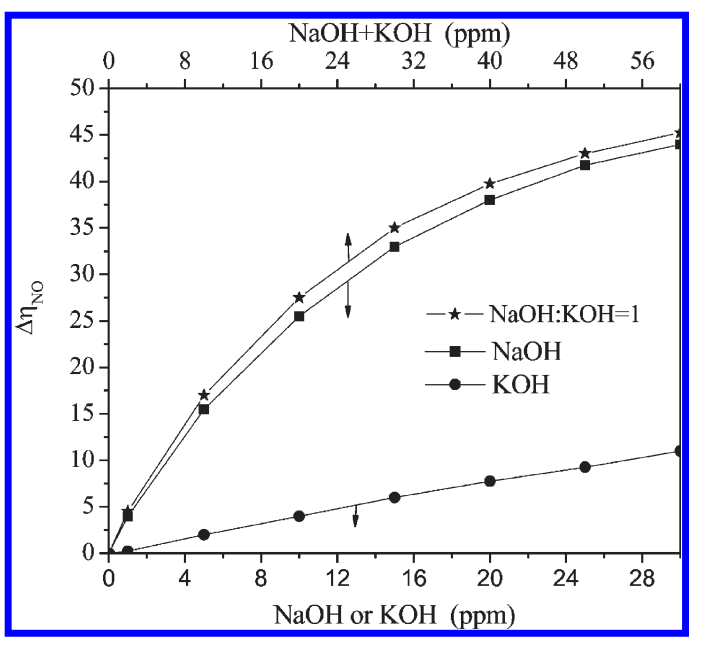

Figure 5. Influence of the concentration of alkali hydroxide vapor on the NO reduction rate: $(\mathbf{O})$ only $\mathrm{KOH}$ releases, $(\boldsymbol{\square})$ only $\mathrm{NaOH}$ releases, and $(\star)$ both $\mathrm{KOH}$ and $\mathrm{NaOH}$ release and the concentration ratio of $\mathrm{NaOH} / \mathrm{KOH}$ is 1 .

and $C_{2, \mathrm{NO}}$ is the $\mathrm{NO}$ emission concentration in the presence of alkali metal vapor. Figure 5 shows the influences of the concentrations of alkali hydroxide vapors on the NO reduction rate, and it indicates that the $\mathrm{NO}$ reduction rate increases with the increase of concentrations of alkali hydroxide vapors. When $\mathrm{KOH}$ and $\mathrm{NaOH}$ are separately present, $\mathrm{NaOH}$ can more effectively enhance the NO reduction rate, as compared to $\mathrm{KOH}$. When $\mathrm{KOH}$ and $\mathrm{NaOH}$ are simultaneously present, the $\mathrm{NO}$ reduction rate slightly increases on the basis of that of $\mathrm{NaOH}$. Thereby, the effect of $\mathrm{NaOH}$ on $\mathrm{NO}$ reduction is much greater than that of $\mathrm{KOH}$.
Figure 6 shows the variations of gaseous composition concentrations with the reaction time in the presence of $\mathrm{KOH}$ (20 ppm) and $\mathrm{NaOH}(20 \mathrm{ppm})$ vapors during biomass reburning at $T=1700 \mathrm{~K}$. NaOH makes the $\mathrm{NO}$ concentration noticeably decrease with the reaction time, as compared to $\mathrm{KOH}$, and the concentrations of $\mathrm{OH}, \mathrm{H}, \mathrm{NH}_{2}$, and $\mathrm{NH}$ are much lower at $t=0-0.04 \mathrm{~s}$ and higher at $t=0.04-0.4 \mathrm{~s}$ (see Figure 6). The modeling results indicate that $\mathrm{NaOH}$ can effectively inhibit $\mathrm{H}$ and $\mathrm{OH}$ formation at the beginning stage and subsequently promote $\mathrm{H}$ and $\mathrm{OH}$ formation at the later stage, and this is conducive to $\mathrm{NO}$ reduction. $\mathrm{KOH}$ can slightly control the free-radical concentration of $\mathrm{H}$ and $\mathrm{OH}$ at the whole stage.

The presence of alkali metal hydroxide vapors during reburning influences free-radical concentrations and $t$ NO ROP, and the top seven $\mathrm{NO}$ production rates of reactions are presented in Figure 7. Because NO production rates of reactions are very stable and approach constants at $t>0.1 \mathrm{~s}$, NO ROP is not provided at $t=0.1-0.4 \mathrm{~s}$ in Figure 7. A comparison of Figures 1 and 7 indicates that, in the presence of $\mathrm{NaOH}, \mathrm{NO}$ ROPs are noticeably inhibited at the beginning stage, NO ROPs of reactions approach 0 , expect for that of $\mathrm{R} 5\left(\mathrm{NH}_{2}+\mathrm{NO}=\mathrm{N}_{2}+\mathrm{H}_{2} \mathrm{O}\right)$, which keeps a negative constant for $\mathrm{NO}$ reduction at $t>0.04 \mathrm{~s}$, and $\mathrm{R} 5$ is the most important reaction for $\mathrm{NO}$ reduction in the whole reaction process. In the presence of $\mathrm{KOH}, \mathrm{NO}$ ROPs are slightly inhibited at the beginning stage but the difference of $\mathrm{NO}$ ROPs of reactions in Figures 1 and $7 \mathrm{~b}$ is little at $t>0.04 \mathrm{~s}$.

To analyze NO reduction pathways in the presence of alkali metal hydroxides, the reaction pathway diagrams for $\mathrm{N}-$, $\mathrm{Na}-$, and $\mathrm{K}$-containing species at the beginning of biomass reburning (0.004 s) are illustrated in Figures 8 and 9. A comparison of Figures 3, 8, and 9 indicate that, in the presence of $\mathrm{NaOH}$ or $\mathrm{KOH}$, the reaction pathways of $\mathrm{N}$-containing species are similar to those in the absence of alkali metals. NO-Reducing agents 

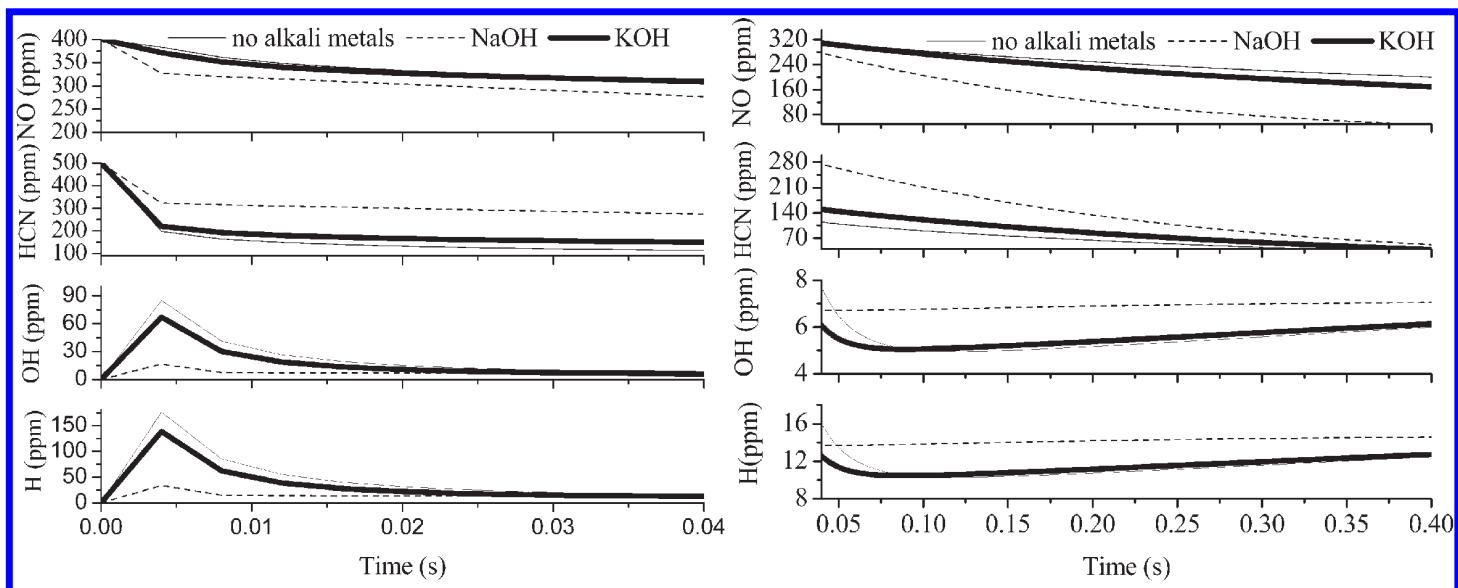

(a) Free radical concentrations of $\mathrm{NO}, \mathrm{HCN}, \mathrm{H}$ and $\mathrm{OH}$
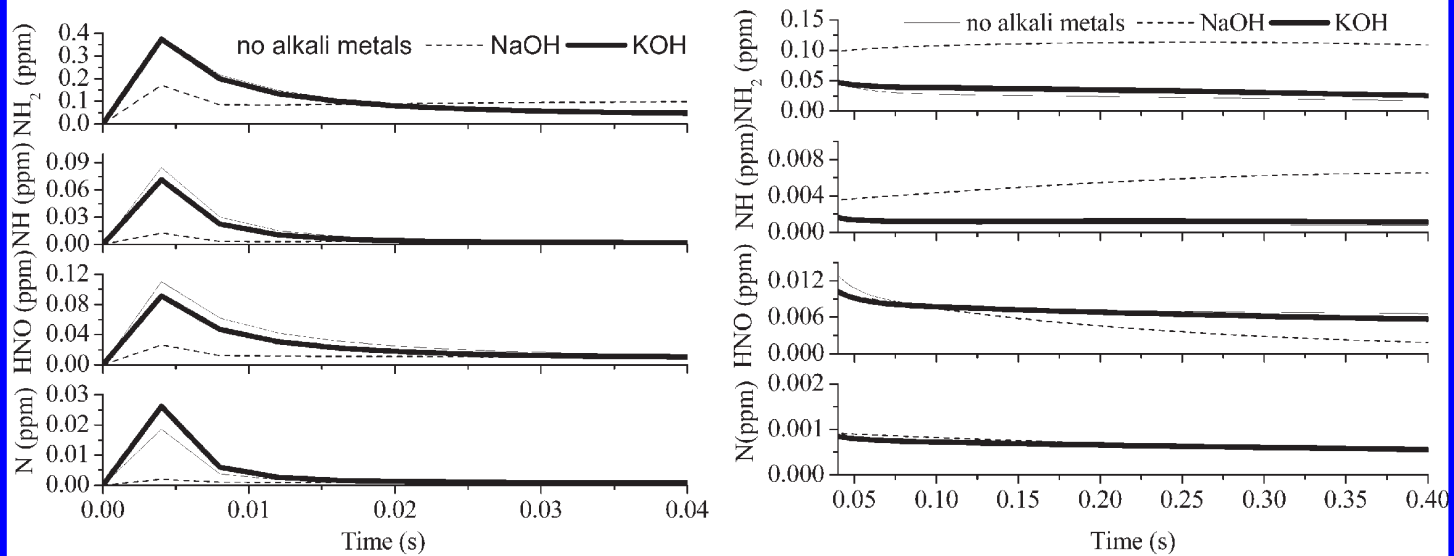

(b) Free radical concentrations of $\mathrm{NH} 2, \mathrm{HNO}$ and $\mathrm{N}$

Figure 6. Variations of gaseous composition concentrations with the reaction time in the presence of $\mathrm{KOH}$ and $\mathrm{NaOH}$ vapors (initial concentration of $20 \mathrm{ppm}$ ): (a) free-radical concentrations of $\mathrm{NO}, \mathrm{HCN}, \mathrm{H}$, and $\mathrm{OH}$ and (b) free-radical concentrations of $\mathrm{NH}_{2}, \mathrm{HNO}$, and $\mathrm{N}$.

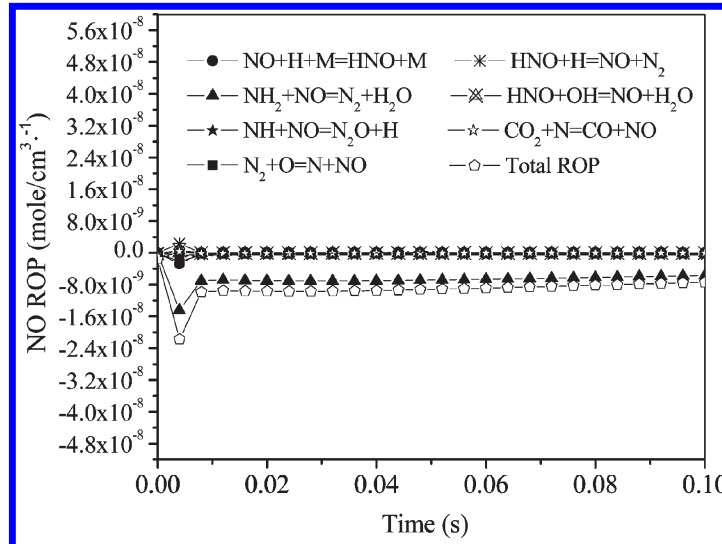

(a) in the presence of $\mathrm{NaOH}$

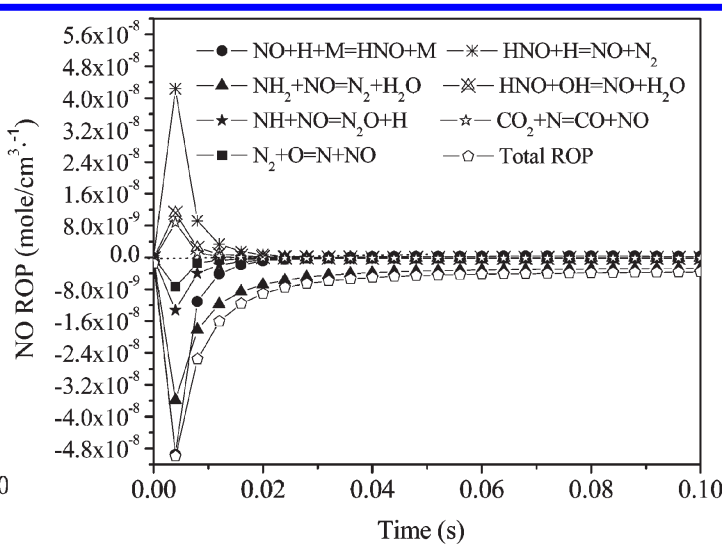

(b) in the presence of $\mathrm{KOH}$

Figure 7. NO ROP versus the reactor time in the presence of $\mathrm{KOH}$ and $\mathrm{NaOH}$ (initial concentration of $20 \mathrm{ppm}$ ): (a) in the presence of $\mathrm{NaOH}$ and (b) in the presence of $\mathrm{KOH}$.

$\left(\mathrm{NH}_{2}, \mathrm{NH}\right.$, and $\left.\mathrm{N}\right)$ derive from $\mathrm{HCN}$, and $\mathrm{HCN}$ plays a critical role in $\mathrm{NO}$ reduction. In the presence of $\mathrm{NaOH}$ and $\mathrm{KOH}$, the contributions of $\mathrm{NH}_{2}$ for $\mathrm{NO}$ reduction are 93 and $71 \%$, respectively. The difference is because the concentrations of $\mathrm{H}$ and $\mathrm{OH}$ in the presence of $\mathrm{NaOH}$ are lower than that in the presence of $\mathrm{KOH}$ (see Figure 6). The low concentrations of $\mathrm{H}$ 


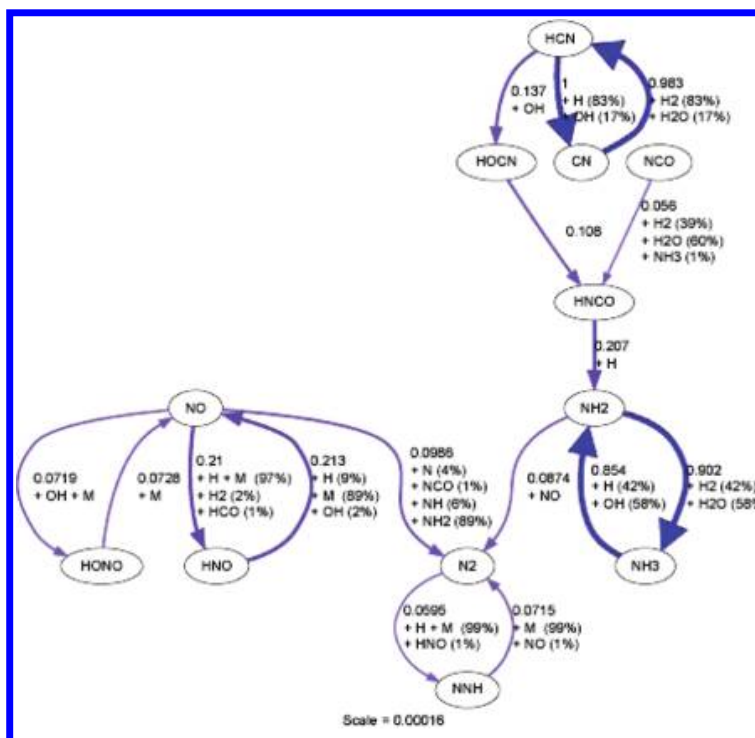

(a) Reaction pathway diagram for $\mathrm{N}$-containing species

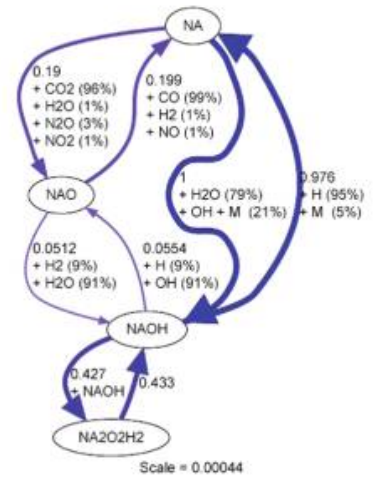

(b) Reaction pathway diagram for Na-containing species

Figure 8. Reaction pathway diagrams for $\mathrm{N}$ - and $\mathrm{Na}$-containing species in the presence of $\mathrm{NaOH}$ (initial concentration of $20 \mathrm{ppm}$ ) at $t=0.004 \mathrm{~s}$ : (a) reaction pathway diagram for $\mathrm{N}$-containing species and (b) reaction pathway diagram for $\mathrm{Na}$-containing species.

and $\mathrm{OH}$ are not conducive to the conversion of $\mathrm{NH}_{2}$ into $\mathrm{NH}$ and $\mathrm{N}$, and thus, $\mathrm{NH}_{2}$ has a higher contribution for $\mathrm{NO}$ reduction in the presence $\mathrm{NaOH}$ at the beginning stage of biomass reburning.

At the later stage, the reaction pathway diagrams for $\mathrm{N}$-containing species are similar to those at the beginning of biomass reburning ( $0.004 \mathrm{~s})$ and, thus, the reaction pathway diagrams are not presented. In the presence of $\mathrm{NaOH}$, the contribution of $\mathrm{NH}_{2}$ for $\mathrm{NO}$ reduction increases from 89 to $93 \%$ at $t=$ $0.004-0.032 \mathrm{~s}$ and keeps constant $(93 \%)$ at $t=0.032-0.4 \mathrm{~s}$. In the presence of $\mathrm{KOH}$, the contribution of $\mathrm{NH}_{2}$ for $\mathrm{NO}$ reduction increases from 71 to $90 \%$ at $t=0.004-0.02 \mathrm{~s}$ and keeps constant (90\%) at $t=0.02-0.4 \mathrm{~s}$. In the presence of $\mathrm{KOH}$, because $\mathrm{HCN}$ is significantly consumed at the beginning stage, the concentrations of $\mathrm{NO}$ reduction agents $\left(\mathrm{NH}_{2}\right.$ and $\left.\mathrm{NH}\right)$ are low at a later stage of the reaction (see Figure 6), and this makes $\mathrm{NO}$ reduction difficult. In the presence of $\mathrm{NaOH}$, because $\mathrm{HCN}$ is not significantly consumed at the beginning stage, the concentrations of $\mathrm{NO}$-reducing agents $\left(\mathrm{NH}_{2}\right.$ and $\left.\mathrm{NH}\right)$ are relative high at a later stage of the reaction (see Figure 6), and this then makes NO reduction easy.

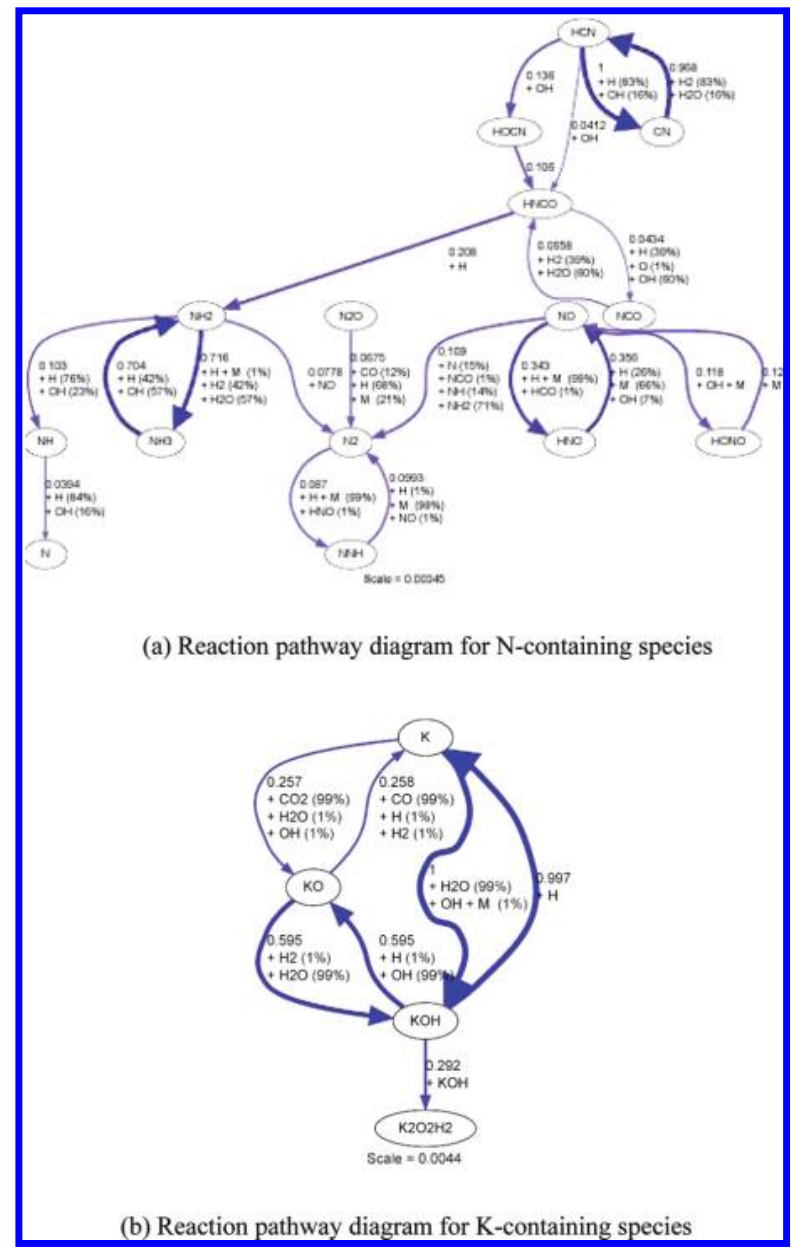

Figure 9. Reaction pathway diagrams for $\mathrm{N}$ - and $\mathrm{K}$-containing species in the presence of $\mathrm{KOH}$ (initial concentration of $20 \mathrm{ppm}$ ) at $t=0.004 \mathrm{~s}$ : (a) reaction pathway diagram for $\mathrm{N}$-containing species and (b) reaction pathway diagram for K-containing species.

Therefore, NO reduction strongly depends upon the local combustion environment, and the free-radical concentrations of $\mathrm{H}$ and $\mathrm{OH}$ influence $\mathrm{NO}$ reduction during biomass reburning. In the beginning stage, the concentration of the reburning fuel is high, its reaction with oxygen forms a large radical pool, the radicals initiate a rapid reaction between $\mathrm{HCN}$ and $\mathrm{NO}, \mathrm{HCN}$ is rapidly depleted, and this is not conducive to NO reduction at a later stage.

Vitali et al. ${ }^{36,37}$ have researched the effect of sodium salt on $\mathrm{NO}$ formation in combustion. The presence of alkali vapors tends to reduce the radical pool in the combustion system, and $\mathrm{Na}$ and $\mathrm{K}$ present "remove" the active oxidation species $(\mathrm{OH}$ and $\mathrm{H}$ ) and inhabit NO formation. ${ }^{38}$ The same behaviors were encountered experimentally and discussed by Zamansky et al. ${ }^{12}$ In Figure $8 b$, the reactions of $\mathrm{Na}$ and $\mathrm{NaOH}$ at high temperatures $(1700 \mathrm{~K})$ consume $\mathrm{H}$ and $\mathrm{OH}$ radicals by the following reactions:

$$
\begin{aligned}
& \mathrm{NaOH}+\mathrm{H} \rightarrow \mathrm{Na}+\mathrm{H}_{2} \mathrm{O} \\
& \mathrm{Na}+\mathrm{OH} \rightarrow \mathrm{NaOH} \\
& \mathrm{NaOH}+\mathrm{NaOH} \rightarrow \mathrm{Na}_{2} \mathrm{O}_{2} \mathrm{H}_{2}
\end{aligned}
$$

The net effect of R18 and R19 is the recombination of active species $\left(\mathrm{H}+\mathrm{OH}=\mathrm{H}_{2} \mathrm{O}\right)$. Figure 10 shows the variations 


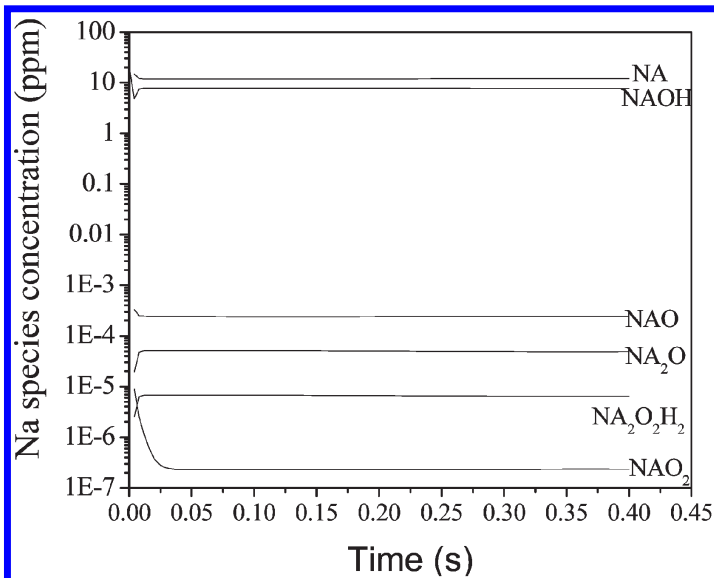

(a) in the presence of $\mathrm{NOH}$

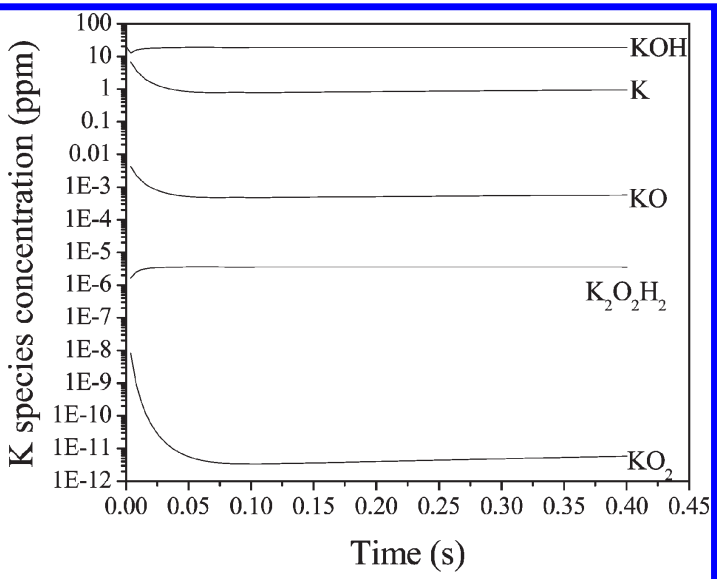

(b) in the presence of $\mathrm{KOH}$

Figure 10. Variations of $\mathrm{Na}$ - and $\mathrm{K}$-containing species concentrations with the reaction time in the presence of $\mathrm{NaOH}$ and $\mathrm{KOH}$ (initial concentration of $20 \mathrm{ppm}$ ): (a) in the presence of $\mathrm{NOH}$ and (b) in the presence of $\mathrm{KOH}$.

of Na- and K-containing species concentrations with the reaction time. It indicates that the concentrations of $\mathrm{NaOH}$ and $\mathrm{Na}$ are higher than that of $\mathrm{Na}_{2} \mathrm{O}, \mathrm{NaO}_{2}$, and $\mathrm{Na}_{2} \mathrm{O}_{2} \mathrm{H}_{2}$, and then the reaction path of $\mathrm{Na}(\mathrm{NaOH} \rightarrow \mathrm{Na} \rightarrow \mathrm{NaOH})$ controls the concentrations of $\mathrm{H}$ and $\mathrm{OH}$ to affect $\mathrm{NO}$ reduction (see Figure $8 \mathrm{~b}$ ).

At the beginning stage of biomass reburning, the concentrations of $\mathrm{H}$ and $\mathrm{OH}$ are in super-equilibrium and it is 2 orders of magnitude greater than its equilibrium value without the release of alkali metals (see Figure 6a). The presence of $\mathrm{NaOH}$ can effectively control the free-radical concentrations of $\mathrm{H}$ and $\mathrm{OH}$ to low levels (see Figure 6a). This reduces the formation of NO-reducing agents $\left(\mathrm{NH}_{2}, \mathrm{NH}\right.$, and $\left.\mathrm{N}\right)$ by R1, R2, R6, R7, R9, and $\mathrm{R} 10$, and thus, the $\mathrm{NO}$ reduction rate of $\mathrm{R} 5$ slightly decreases, as compared to Figures 1 and $7 \mathrm{a}$. In the meantime, the presence of $\mathrm{NaOH}$ can inhibit the conversion of $\mathrm{HCN}$ into $\mathrm{NH}, \mathrm{HNO}$, and $\mathrm{N}$ because of low concentrations of $\mathrm{H}$ and $\mathrm{OH}$, and this avoids the NO formation through the consumption of a large amount of HCN by R13 and R17 at the beginning stage of biomass reburning.

At the later stage of biomass reburning, the concentrations of $\mathrm{H}$ and $\mathrm{OH}$ reach low-level equilibrium, an increase of the concentration of $\mathrm{H}$ and $\mathrm{OH}$ is conducive to the conversion of HCN into $\mathrm{NH}_{2}$, and $\mathrm{NO}$ is reduced to $\mathrm{N}_{2}$ by the reaction pathway $\mathrm{HCN} \rightarrow \mathrm{HOCH} / \mathrm{HNCO} \rightarrow \mathrm{NH}_{2}+\mathrm{NO} \rightarrow \mathrm{N}_{2}+\mathrm{H}_{2} \mathrm{O}$. The presence of $\mathrm{NaOH}$ can make the concentrations of $\mathrm{H}$ and $\mathrm{OH}$ sustain relatively high levels by the reaction path of $\mathrm{Na}$ $(\mathrm{NaOH} \rightarrow \mathrm{Na} \rightarrow \mathrm{NaOH}$ ) (see Figure $8 \mathrm{~b}$ ). $\mathrm{HCN}$ is kept sufficient for NO reduction (see Figure 6a) because of the low consumption of $\mathrm{HCN}$ at the reaction beginning stage.

xIn other words, during biomass reburning, the reactions of $\mathrm{Na}$-containing species can sustain the relative high rates of NO reduction by controlling the free-radical concentrations of $\mathrm{H}$ and $\mathrm{OH}$, and thus, $\mathrm{Na}$-containing species is very important for $\mathrm{NO}$ reduction.

In the meantime, $\mathrm{Na}$ species can process following reaction

$$
\begin{aligned}
& \mathrm{Na}+\mathrm{N}_{2} \mathrm{O} \rightarrow \mathrm{NaO}+\mathrm{N}_{2} \\
& \mathrm{NaO}+\mathrm{CO} \rightarrow \mathrm{Na}+\mathrm{CO}_{2} \\
& \text { net: } \mathrm{N}_{2} \mathrm{O}+\mathrm{CO} \rightarrow \mathrm{N}_{2}+\mathrm{CO}_{2}
\end{aligned}
$$

The net effect of $\mathrm{R} 21$ and $\mathrm{R} 22$ is that $\mathrm{N}_{2} \mathrm{O}$ is destroyed to form $\mathrm{N}_{2}$.

As known from Figures $8 \mathrm{~b}$ and $9 \mathrm{~b}$, the behavior of Kcontaining species is similar to that of $\mathrm{Na}$-containing species, and the similar behaviors of $\mathrm{Na}$ - and $\mathrm{K}$-containing species were found experimentally by Zamansky et al. ${ }^{12}$ The concentrations of $\mathrm{K}$ and $\mathrm{KOH}$ are high in Figure $10 \mathrm{~b}$, and the main reaction pathways of K-containing species in Figure $9 \mathrm{~b}$ are as follows:

$$
\begin{aligned}
& \mathrm{KOH}+\mathrm{H} \rightarrow \mathrm{K}+\mathrm{H}_{2} \mathrm{O} \\
& \mathrm{K}+\mathrm{OH} \rightarrow \mathrm{KOH} \\
& \mathrm{K}+\mathrm{H}_{2} \mathrm{O} \rightarrow \mathrm{KOH}+\mathrm{H}
\end{aligned}
$$

Figure $9 \mathrm{~b}$ indicates that $\mathrm{R} 25$ predominates in $\mathrm{KOH}$ formation and R24 is negligible. In the reaction pathways of $\mathrm{NaOH} \rightarrow$ $\mathrm{Na} \rightarrow \mathrm{NaOH}$ and $\mathrm{KOH} \rightarrow \mathrm{K} \rightarrow \mathrm{KOH}$, the reaction rate constants of $\mathrm{R} 18$ and $\mathrm{R} 23$ are equal but the reaction rate constant of R24 is only ${ }^{1 / 647}$ of R19. R24 limits the cycle reactions of $\mathrm{KOH} \rightarrow \mathrm{K} \rightarrow \mathrm{KOH}$. A high concentration of free radicals of $\mathrm{H}$ and $\mathrm{OH}$ cannot be effectively removed at the beginning time (see Figure 6a), and then, a large amount of $\mathrm{HCN}$ is finally conversed into $\mathrm{NO}$ by $\mathrm{R} 12-\mathrm{R} 17$. At the later stage, because of the low concentration of $\mathrm{H}, \mathrm{OH}$, and $\mathrm{HCN}$, $\mathrm{NO}$ reduction is difficult. Thereby, during biomass reburning, $\mathrm{KOH}$ has less influence on $\mathrm{NO}$ reduction than $\mathrm{NaOH}$.

4.3. NO Reduction by the Release of Alkali Metal Chlorides. It is assumed that $\mathrm{K}$ and $\mathrm{Na}$ species can be released in the vapor forms of hydroxides $(\mathrm{NaCl}$ and $\mathrm{KCl})$, and both $\mathrm{NaCl}$ and $\mathrm{KCl}$ concentrations are $20 \mathrm{ppm}$. The modeling results indicate that the influence of $\mathrm{NaCl}$ and $\mathrm{KCl}$ on the $\mathrm{NO}$ reduction rate is the same as that of $\mathrm{NaOH}$ and $\mathrm{KOH}$ (see Figure 5), and the influence of the concentration of alkali chloride vapors on the NO reduction rate is not provided.

Here, the concentrations of $\mathrm{Na}$ - and $\mathrm{K}$-containing species are presented in Figure 11. In Figure 11a, the concentrations of $\mathrm{Na}, \mathrm{NaCl}$, and $\mathrm{NaOH}$ are high. The result indicates that the reactions involving $\mathrm{Na}, \mathrm{NaCl}$, and $\mathrm{NaOH}$ species are 


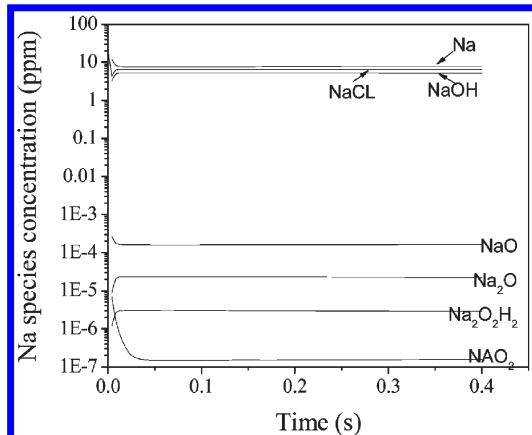

(a)

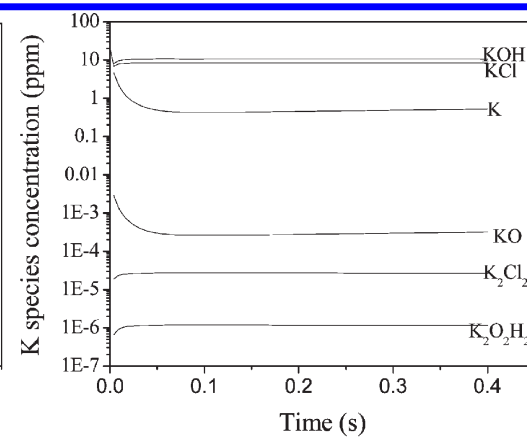

(b)

Figure 11. Variations of $\mathrm{Na}$ - and $\mathrm{K}$-containing species concentrations with the reaction time in the presence of $\mathrm{KOH}$ and $\mathrm{NaOH}$ (initial concentration of $20 \mathrm{ppm}$ ).

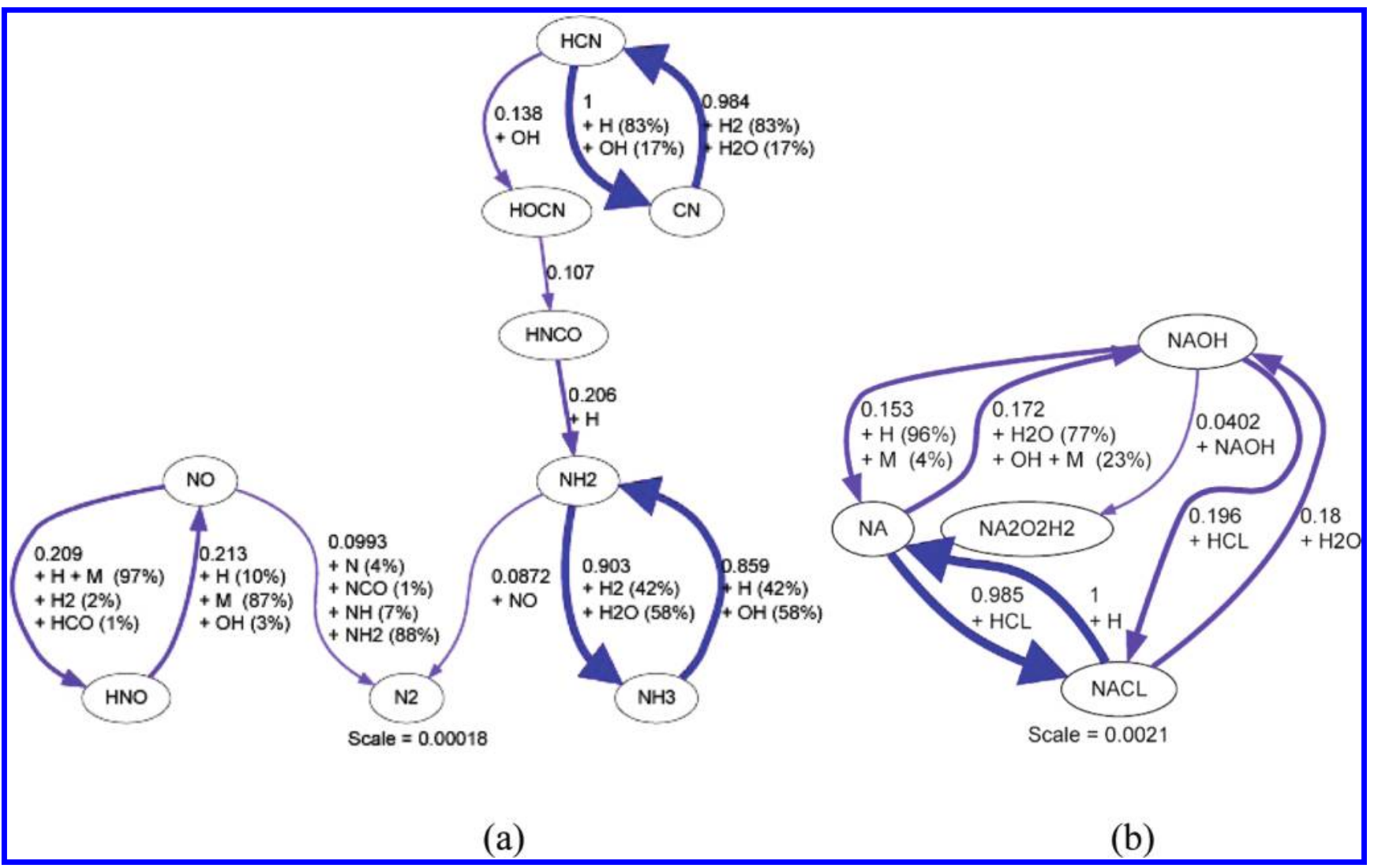

Figure 12. Reaction pathway diagrams for $\mathrm{N}$ - and Na-containing species in the presence of $\mathrm{NaCl}$ during biomass reburning at $t=0.004 \mathrm{~s}$.

dominant in Na-containing reactions, and these important reaction pathways are shown in Figure 12b.

$$
\begin{aligned}
& \mathrm{NaCl}+\mathrm{H}_{2} \mathrm{O}=\mathrm{NaOH}+\mathrm{HCl} \\
& \mathrm{NaCl}+\mathrm{H}=\mathrm{Na}+\mathrm{HCl} \\
& \mathrm{NaOH}+\mathrm{H}=\mathrm{Na}+\mathrm{H}_{2} \mathrm{O} \\
& \mathrm{NaOH}+\mathrm{M}=\mathrm{Na}+\mathrm{OH}+\mathrm{M}
\end{aligned}
$$

Figure 12 shows the reaction pathway diagrams for $\mathrm{N}$ - and $\mathrm{Na}$-containing species in the presence of $\mathrm{NaCl}$ during biomass reburning at $t=0.004 \mathrm{~s}$. When Figure $8 \mathrm{a}$ is compared to Figure 12a, in the presence of $\mathrm{NaOH}$ and $\mathrm{NaCl}$ during biomass reburning, the reaction pathways of $\mathrm{N}$-containing species are similar and the contributions of NO-reducing agents $\left(\mathrm{NH}_{2}, \mathrm{NH}\right.$, and $\mathrm{N}$ ) for $\mathrm{NO}$ reduction are nearly identical. Although $\mathrm{HCl}$ is formed through R26 and R27, Figure 12a indicates that the reaction pathways of $\mathrm{N}$-containing species are not influenced by $\mathrm{HCl}$ during biomass reburning and $\mathrm{HCl}$ formation has no influence on NO emission. Experiments by Wei et al. ${ }^{39}$ also found that $\mathrm{HCl}$ addition has almost no influence on $\mathrm{NO}_{x}$ emissions under fuel-rich combustion conditions.

In the presence of $\mathrm{KCl}$, the reaction pathway of $\mathrm{N}$-containing species is the same as that in the presence of $\mathrm{KOH}$ (see 


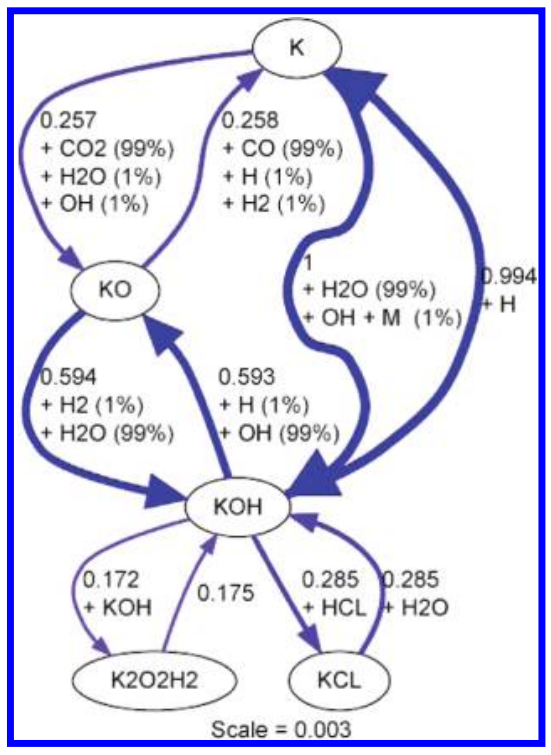

Figure 13. Reaction pathway diagram for K-containing species in the presence of $\mathrm{KCl}$ (initial concentration of $20 \mathrm{ppm}$ ).

Figure 9a); thus, the pathway is not provided. Figure 13 shows the reaction pathway of $\mathrm{K}$-containing species. In Figure $11 \mathrm{~b}$, the concentrations of $\mathrm{KOH}, \mathrm{KCl}$, and $\mathrm{K}$ are high. The reactions involving species $\mathrm{KOH}, \mathrm{KCl}$, and $\mathrm{K}$ are dominant in $\mathrm{K}$-containing reactions, and these important reaction pathways in Figure 13 are as follows:

$$
\begin{aligned}
& \mathrm{KCl}+\mathrm{H}_{2} \mathrm{O}=\mathrm{KOH}+\mathrm{HCl} \\
& \mathrm{KOH}+\mathrm{H}=\mathrm{K}+\mathrm{H}_{2} \mathrm{O}
\end{aligned}
$$

\section{CONCLUSION}

Biomass reburning was simulated using the Sandia SENKIN program, and the promotion mechanism of $\mathrm{NO}$ reduction by $\mathrm{K}$ - and $\mathrm{Na}$-containing species vapor released from biomass was investigated. $\mathrm{Na}$-Containing species have great promotion of $\mathrm{NO}$ reduction by controlling the free radicals of $\mathrm{H}$ and $\mathrm{OH}$, as compared to K-containing species, and the effects of alkali metal hydroxide vapors and alkali metal chloride vapors on the NO reduction rate were identical. At the beginning stage of biomass reburning, $\mathrm{Na}$-containing species can effectively inhibit the conversion of $\mathrm{HCN}$ into $\mathrm{NH}, \mathrm{HNO}$, and $\mathrm{N}$ by controlling the formation of $\mathrm{H}$ and $\mathrm{OH}$ and it avoids $\mathrm{NO}$ formation. At the later stage of biomass reburning, the free-radical levels of $\mathrm{H}$ and $\mathrm{OH}$ reach equilibrium, $\mathrm{Na}$-containing species can promote the formation of $\mathrm{H}$ and $\mathrm{OH}$ to sustain a relatively high level through the chemical reaction path of $\mathrm{NaOH} \rightarrow \mathrm{Na} \rightarrow \mathrm{NaOH}$, and $\mathrm{NO}$ is effectively reduced. Because the reaction rate constant of $\mathrm{K}+\mathrm{OH}=$ $\mathrm{KOH}$ is only ${ }^{1} /{ }_{64}$ of $\mathrm{Na}+\mathrm{OH}=\mathrm{NaOH}, \mathrm{KOH}$ has low promotion of $\mathrm{NO}$ reduction, as compared to $\mathrm{NaOH}$.

\section{AUTHOR INFORMATION}

\section{Corresponding Author}

*Telephone/Fax: +86-10-82544231. E-mail: lisen@imechac.cn.

\section{ACKNOWLEDGMENT}

Financial support by the National Natural Science Foundation of China (50976123 and 50776099) and the Knowledge
Innovation Program of the Chinese Academy of Sciences (KGCX2-YW-321) is acknowledged.

\section{REFERENCES}

(1) Li, S.; Xu, T. M.; Zhou, Q. L.; Tan, H. Z.; Hui, S E.; Hu, H. L. Fuel 2007, 86, 1169-1175.

(2) Hald, P. Prepr. Pap.-Am. Chem. Soc. Div. Fuel Chem. 1995, $40,753-757$.

(3) Dayton, D. C.; French, R. J.; Milne, T. A. Energy Fuels 1995, 9, 855-865.

(4) Zamansky, V. M.; Sheldon, M. S.; Lissianski, V. V.; Maly, P. M.; Moyeda, D. K.; Marquez, A.; Seeker, W. R. Advanced Biomass Reburning for High Efficiency $\mathrm{NO}_{x}$ Control; GE Energy and Environmental Research Corporation: Irvine, CA, 2000; Department of Energy (DOE), National Energy Technology Laboratory (NETL) Contract DE-FC26-97FT-97270.

(5) Lissianski, V. V.; Zamansky, V. M.; Maly, P. M. Biomass Reburning-Modelling/Engineering; GE Energy and Environmental Research Corporation: Irvine, CA, 1999; Department of Energy (DOE), National Energy Technology Laboratory (NETL) Contract DE-FC26-97FT97270.

(6) Munir, S.; Nimmo, W.; Gibbs, B. M. J. Qual. Technol. Manage. 2010, 6, 43-79.

(7) Nimmo, W.; Liu, H. Developments in $\mathrm{NO}_{x}$ emission control by reburning in pulverised coal combustion. In Coal Combustion Research; Grace, C. T., Ed.; Nova Science Publishers, Inc.: Hauppauge, NY, 2010; pp $85-170$.

(8) Nimmo, W.; Singh, S.; Gibbs, B. M.; Williams, P. T. Fuel 2008, $87,2893-2900$.

(9) Hampartsoumian, E.; Folayan, O. O.; Nimmo, W.; Gibbs, B. M. Fuel 2003, 82, 373-384.

(10) Nimmo, W.; Patsias, A. A.; Hall, W.; Williams, P. T. Ind. Eng. Chem. Res. 2005, 44, 4484-4494.

(11) Ballester, J.; Ichaso, R.; Pina, A.; González, M. A.; Jiménez, S. Biomass Bioenergy 2008, 32, 959-970.

(12) Zamansky, V. B.; Ho, L.; Maly, P. M.; Seeker, W. R. Proc. Combust. Inst. 1996, 26, 2075-2082.

(13) Lee, S.; Park, K.; Park, J. W.; Kim, B. H. Combust. Flame 2005, 141, 200-203.

(14) Liu, Y. H.; Liu, Y. H.; Che, D. F.; Xu, T. M. Proc. Chin. Soc. Electr. Eng. 2005, 25, 136-141.

(15) Avelina, G. G.; María, J. I. G.; Angel, L. S.; Concepción, S. M. L. Fuel 1997, 76, 499-505.

(16) Sjaak, V. L.; Jaap, K. The Handbook of Biomass Combustion and Co-firing; EarthScan: Oxford, U.K., 2008.

(17) Dayton, D. G.; Milne, T. A. Proceedings of the 21th National Meeting of the American Chemical Society, Division of Fuel Chemistry; Chicago, IL, 1995; pp 758-762.

(18) Chenevert, B. C.; Kramlich, J. C.; Nichols, K. M. Proc. Combust. Inst. 1999, 27, 1719-1725.

(19) Sandia National Laboratories. SENKIN: A Fortran Program for Predicting Homogeneous Gas Phase Chemical Kinetics with Sensitivity Analysis; Sandia National Laboratories: Livermore, CA, 1988; SAND87-8248.

(20) Sandia National Laboratories. CHEMKIN-II: A Fortran Chemical Kinetics Package for the Analysis of Gas Phase Chemical Kinetics; Sandia National Laboratories: Livermore, CA, 1989; SAND89-8009B.

(21) Cantera: Object-Oriented Software for Reacting Flows; http:// www.cantera.org.

(22) Dagaut, P.; Lecomte, F.; Chevailler, S.; Cathonnet, M. Combust. Sci. Technol. 1998, 139, 329-363.

(23) Dagaut, P.; Lecomte, F.; Chevailler, S.; Cathonnet, M. Combust. Flame 1999, 119, 494-504.

(24) Dagaut, P.; Luche, J.; Cathonnet, M. Proc. Combust. Inst. 2000, $28,2459-2465$.

(25) Dagaut, P.; Lecomte, F. Energy Fuels 2003, 17, 608-613.

(26) Zamansky, V. M.; Maly, P. M.; Lissianski, V. V.; Sheldon, M. S.; Moyeda, D.; Payne, R. Secondary Generation Advanced Reburning for High 
Efficiency $\mathrm{NO}_{x}$ Control; GE Energy and Environmental Research Corporation: Irvine, CA, 2001; DOE Contract DE-AC22-95PC95251.

(27) Glarborg, P.; Marshall, P. Combust. Flame 2005, 141, 22-39.

(28) Hindiyarti, L.; Frandsen, F.; Livbjerg, H.; Glarborg, P.; Marshall, $\underline{\text { P. }}$ Fuel 2008, 87, 1591-1600.

(29) Dagaut, P.; Lecomte, F. Fuel 2003, 82, 1033-1040.

(30) Chen, Y.; Charpenay, S.; Jensen, A.; Wójtowicz, M. A.; Serio, M. A. Proc. Combust. Inst. 1999, 27, 1327-1334.

(31) Williams, A.; Pourkashanian, M.; Jones, J. M. Proceedings of the 5th International Conference on Technologies and Combustion for a Clean Environment; Lisbon, Portugal, 1999; pp 945-952.

(32) Cantera: Object-Oriented Software for Reacting Flows; http:// www.cantera.org.

(33) Dryer, F. L.; Glassman, I. Proceedings of the 14th International Symposium on Combustion; The Combustion Institute: Pittsburgh, PA, 1973.

(34) Hardy, J. E.; Lyon, R. K. Combust. Flame 1980, 39, 317-320.

(35) El-Mahallawy, F.; E-Din Habik, S. Fundamentals and Technology of Combustion; Elsevier Science: Amsterdam, The Netherlands, 2002.

(36) Yang, W.; Zhou, J.; Liu, M.; Zhou, Z.; Liu, J.; Cen, K. Energy Fuels 2007, 21, 2548-2554.

(37) Lissianski, V. V.; Zamansky, V. M.; Maly, P. M. Combust. Flame 2001, 125, 1118-1127.

(38) Carucci, J. R. H.; Kilpinen, P. Turk. I. Eng. Environ. Sci. 2006, 30, 163-174.

(39) Wei, X. L.; Han, X. H.; Schnell, U.; Maier, J.; Worner, H.; Hein, K. R. G. Energy Fuels 2003, 17, 1392-1398. 